\title{
Faktor-Faktor yang Berhubungan dengan Stres Kerja Pada Petugas Pemadam Kebakaran Kompi C di Kota Padang
}

\author{
Putri Permatasari $\left.{ }^{1 *}\right)$ Hendra $^{2}$, \\ ${ }^{1}$ Universitas Pembangunan Nasional Veteran Jakarta \\ ${ }^{2}$ Sekolah Tinggi Ilmu Kesehatan Alifah Padang \\ ${ }^{1}$ ppermatasari8@gmail.com ${ }^{*}$; ${ }^{2}$ stikes_alifah@yahoo.com
}

\section{ARTICLE INFO}

Article history:

Received 11 December 2017

Revised 5 February 2018

Accepted 11 February 2018

\section{Keyword:}

Work Stress

Firefighters, Workload

A Routine Work

Work Environment

*) corresponding author

DOI:http://dx.doi.org/10.30604/jika.v3i1.64

A B S T R A C T

Stress is actually a form of response to a person, both physically and mentally, to a change in the environment that felt annoying and cause self in danger. One of the professions that have a very high risk of exposure to stress is a firefighters. This study was conducted in Fire department South Padang in May - June 2016. Study sample as many as 116 respondents. In this study, analysis performed descriptive analyzes to look at the picture of the frequency distribution of each variable both dependent and independent variables, including: work stress, workload, a routine work, work environment, interpersonal relations with a boss, interpersonal relations with colleagues, promotion (the increase in the level of office), salary, a role in the organization, family problems, economic issues and type of personality. While the bivariate analysis aims to see whether the relationship between the independent variables and the dependent variable and observed differences in the frequency value. Based on the results study, firefighters who experienced job stress as much as 29,3 percent. While the variables that have an association with job stress events such as workload ( $p$-value = $0,020)$, a routine work ( $p$-value $=0,033$ ), and promotion (the increase in the level of office) ( $p$-value $=0,024)$. There are some suggestions that can of work stress in firefighters by held a relaxation activities and conduct spiritual cleansing.
\end{abstract}

Copyright (C) 2018, Jurnal Aisyah: Jurnal Ilmu Kesehatan.

All rights reserved.

\section{PENDAHULUAN}

Pertumbuhan ekonomi yang selalu tinggi sejak bertahun-tahun dan perubahan sosial yang sangat cepat mengakibatkan pekerja kita mengalami banyak stres mulai dari berangkat kerja, dipekerjaan, pulang kerja dan di rumah. Makin lama dirasakan pekerjaan makin berat, lama dan banyak tetapi penghasilan masih dirasakan kurang. Salah satu hal yang diperhatikan dalam menjaga kualitas sumber daya manusia sebagai pekerja adalah dengan diterapkannya Keselamatan dan Kesehatan Kerja (K3). 
Keselamatan dan kesehatan kerja (K3) merupakan suatu ilmu terapan yang sangat penting dalam keseharian hidup umat manusia, khususnya pekerja. Sesuai dengan definisi K3 menurut WHO/ILO, K3 adalah upaya promosi dan memelihara derajat tertinggi semua pekerja baik fisik, mental dan kesejahteraan sosial di semua jenis pekerjaan.

Stres kerja diketahui menyebabkan berbagai permasalahan kesehatan kerja. Kemajuan dan perkembangan teknologi memperlambat kemampuan manusiauntuk mempertahankan produktivitas sehingga menjadi lebih rentan terkena stres kerja (National Safety Council, 1994). Hal ini menjadikan industrialisasi yang didorong oleh adanya globalisasi memiliki efek negatif bagi para pekerja itu sendiri. Setiap tahunnya, di Inggris terdapat enam juta penduduk yang terkena gangguan mental seperti depresi dan kegelisahan.

Sebuah survey yang dilakukan oleh Institut Nasional untuk Keamanan dan Keselamatan Kerja (NIOSH) menemukan bahwa 25 persen dari orang yang disurvey melaporkan bahwa pekerjaan mereka merupakan satu-satunya sumber stres terbesar di dalam kehidupan mereka. Kurang lebih satu juta orang absen kerja setiap hari karena masalah yang terkait dengan stres.

Lebih dari 250.000 hari kerja hilang setiap tahun karena stres. Stres kerja membuat para pemberi kerja di Amerika mengalami kerugian antara 200-300 miliar dollar setahun. Arden (2002) menyebutkan lima pekerjaan yang lebih menimbulkan stress dibandingkan pekerjaan lainnya karena karakteristik yang ada pada pekerjaantersebut.Karakteristik pekerjaan termasuk di dalam sumber stress (stressor). Lima pekerjaan tersebut meliputi pengatur lalu lintas udara, polisi, perawat ruang gawat darurat, paramedic dan pemadam kebakaran.

Pemadam kebakaran merupakan salah satu pekerjaan yang memiliki potensi dengan tingkat stres tinggi dibandingkan dengan pekerjaan lainnya. Hal ini didorong oleh karakteristik pekerjaan tersebut yang mengharuskan pekerja berhadapan dengan berbagai bahaya serta risiko yang terdapat pada pekerjaan pemadam kebakaran. Ditambah dengan adanya tugas memadamkan sebuah kebakaran yang seringkali terjadi di luar jam kerja pekerja lainnya. Berdasarkan data Dinas Pemadam Kebakaran dan Penanggulangan Bencana Kota Padang, terhitung sejak awal Januari hingga Desember 2015, sebanyak 394 peristiwa kebakaran menimpa wilayah Kota Padang.

\section{METODE PENELITIAN}

Penelitian ini di lakukan pada bulan April 2016 di Jl. Raya Pasar Jumat Suku Dinas Pemadam Kebakaran Kota Padang. Desain penelitian ini adalah deskriptif analitik yang bersifat kuantitatif. Dimana desain studi yang digunakan merupakan studi cross sectional. Dalam hal ini, pengukuran variabel independen dan variabel dependen dilakukan dalam satuwaktu secara bersamaan dan pada setiap responden hanya dilakukan satu kali penelitian. Selanjutnya pemaparan deskriptif tersebut akan dianalisis untuk menjawab berbagai pertanyaan peneltian yang sudah penulis tentukan di awal.

Instrumen yang digunakan dalam penelitian ini adalah kuesioner. Tujuan uji kuesioner yaitu untuk mengetahui seberapa jauh responden mengerti terhadap pertanyaan yang peneliti ajukan. Kuesioner di berikan kepada petugas yang berada di Kantor Pemadam Kebakaran Kota Padang. Sebelum kuesioner diberikan kepada responden, responden diberikan penjelasan terlebih dahulu tentang maksud dan tujuan penyebaran kuesioner. Sampel dalam penelitian ini adalah petugas yang berada di Kantor Pemadam Kebakaran Kota Padang.

Pengolahan data yang dilakukan dengan menggunakan komputer dengan menggunakan SPSS 16. Analisis data yang digunakan adalah analisis univariat dan 
bivariat. Analisis statistik yang digunakan hubungan yang bermakna diantara dua adalah chi square $\left(\mathrm{X}^{2}\right)$ yaitu untuk melihat variable.

\section{HASIL DAN PEMBAHASAN}

Tabel 1. Hubungan Beban Kerja dengan Stres Kerja.

\begin{tabular}{|c|c|c|c|c|c|c|c|c|}
\hline \multirow{3}{*}{ No } & \multirow{3}{*}{ Beban Kerja } & \multicolumn{4}{|c|}{ Stres Kerja } & \multirow{2}{*}{\multicolumn{2}{|c|}{ Jumlah }} & \multirow{3}{*}{$p$ value } \\
\hline & & \multicolumn{2}{|c|}{$\begin{array}{c}\text { Tidak } \\
\text { Menagalami } \\
\text { Stres Kerja }\end{array}$} & \multicolumn{2}{|c|}{$\begin{array}{l}\text { Menagalami } \\
\text { Stres Kerja }\end{array}$} & & & \\
\hline & & $\mathrm{n}$ & $\%$ & $\mathrm{n}$ & $\%$ & $\mathrm{n}$ & $\%$ & \\
\hline 1 & $\begin{array}{c}\text { Menambahkan } \\
\text { Beban }\end{array}$ & 53 & 45,7 & 14 & 12,1 & 67 & 57,8 & \\
\hline 2 & $\begin{array}{c}\text { Tidak } \\
\text { Menambahakan } \\
\text { Beban }\end{array}$ & 29 & 25,0 & 20 & 17,2 & 49 & 42,2 & 0.020 \\
\hline & Jumlah & 67 & 70,7 & 49 & 29,3 & 116 & 100,0 & \\
\hline
\end{tabular}

Tabel 1 menunjukkan hasil analisis hubungan antara yang tidak mengalami stres kerja dan yang menambahkan beban kerja sebesar 45,7 persen (53 responden) sedangkan yang tidak menambahkan beban kerja sebesar 25,0 persen (29 responden). Yang mengalami stres kerja dan menambahkan beban kerja 12,1 persen (14 responden) sedangkan yang tidak menambahkan beban kerja 17,2 persen (20 responden) Hasil uji statistik diperoleh nilai $p$-value $=0.020$, yang memilliki arti ada hubungan yang bermakna antara stres kerja dengan beban kerja. Hal ini disebabkan karena persepsi responden terhadap kerja tidak melebihi jam kerja kantor, tuntutan kerja cepat, kewalahan akibat pekerjaan yang dikerjakan, kesulitan mengerjakan pekerjaan dan melaksanakan pekerjaan di luar tanggung jawab.

Tabel 2. Hubungan Rutinitas Kerja dengan Stres Kerja.

\begin{tabular}{|c|c|c|c|c|c|c|c|c|}
\hline \multirow{3}{*}{ No } & \multirow{3}{*}{ Rutinitas Kerja } & \multicolumn{4}{|c|}{ Stres Kerja } & \multirow{2}{*}{\multicolumn{2}{|c|}{ Jumlah }} & \multirow{3}{*}{ p value } \\
\hline & & \multicolumn{2}{|c|}{$\begin{array}{c}\text { Tidak } \\
\text { Mengalami } \\
\text { Stres Kerja }\end{array}$} & \multicolumn{2}{|c|}{$\begin{array}{l}\text { Mengalami } \\
\text { Stres Kerja }\end{array}$} & & & \\
\hline & & $\mathrm{n}$ & $\%$ & $\mathrm{n}$ & $\%$ & $\mathrm{n}$ & $\%$ & \\
\hline 1 & Membosankan & 44 & 37,9 & 52 & 44,8 & 96 & 82,8 & \\
\hline 2 & $\begin{array}{c}\text { Tidak } \\
\text { Membosankan }\end{array}$ & 4 & 3,4 & 16 & 13,8 & 20 & 17,2 & 0.033 \\
\hline & Jumlah & 48 & 41,4 & 68 & 58,6 & 116 & 100,0 & \\
\hline
\end{tabular}

Tabel 2 menunjukkan hasil analisis hubungan antara yang tidak mengalami stres kerja dan rutinitas kerja yang membosankan sebesar 37,9 persen (44 responden) sedangkan rutinitas kerja yang tidak membosankan sebesar 3,4 persen (4 responden). Yang mengalami stres kerja dan rutinitas kerja yang membosankan 44,8 persen $(52$ responden) sedangkan rutinitas kerja yang tidak membosankan sebesar 13,8 persen (16 responden). Hasil uji statistik diperoleh nilai $p$-value $=0.033$, yang memiliki arti ada hubungan yang bermakna antara stres kerja dengan rutinitas kerja. Hal ini disebabkan karena pekerjaan yang monoton, pekerjaan membosankan dan lain sebagainya. 
Tabel 3. Hubungan Suasana Lingkungan Kerja dengan Stres Kerja.

\begin{tabular}{|c|c|c|c|c|c|c|c|c|}
\hline \multirow{3}{*}{ No } & \multirow{3}{*}{$\begin{array}{c}\text { Suasana } \\
\text { Lingkungan } \\
\text { Kerja }\end{array}$} & \multicolumn{4}{|c|}{$\begin{array}{l}\text { Stres Kerja } \\
\end{array}$} & \multirow{2}{*}{\multicolumn{2}{|c|}{ Jumlah }} & \multirow[b]{2}{*}{ p value } \\
\hline & & \multicolumn{2}{|c|}{$\begin{array}{c}\text { Tidak } \\
\text { Menagalami } \\
\text { Stres Kerja }\end{array}$} & \multicolumn{2}{|c|}{$\begin{array}{l}\text { Menagalami } \\
\text { Stres Kerja }\end{array}$} & & & \\
\hline & & $\mathrm{n}$ & $\%$ & $\mathrm{n}$ & $\%$ & $\mathrm{n}$ & $\%$ & \\
\hline 1 & Membosankan & 22 & 19,0 & 27 & 23,3 & 49 & 42,2 & \\
\hline 2 & $\begin{array}{c}\text { Tidak } \\
\text { Membosankan }\end{array}$ & 30 & 25,9 & 37 & 31,9 & 67 & 57,8 & 0.990 \\
\hline & Jumlah & 52 & 44,8 & 64 & 55,2 & 116 & 100,0 & \\
\hline
\end{tabular}

Tabel 3 didapatkan hasil analisis hubungan antara yang tidak mengalami stres kerja dan suasana lingkungan kerja yang membosankan sebesar 19,0 persen (22 responden) sedangkan suasana lingkungan kerja yang tidak membosankan sebesar 25,9 persen (30 responden). Yang mengalami stres kerja dan suasana lingkungan yang membosankan 23,3 persen (27 responden) sedangkan suasana lingkungan yang tidak membosankan sebesar 31,9 persen (37 responden). Hasil uji statistik diperoleh nilai $p$-value $=0.990$, yang memiliki arti tidak ada hubungan yang bermakna antara stres kerja dengan suasan lingkungan kerja.

Tabel 4. Hubungan Interpersonal dengan (Atasan) dengan Stres Kerja.

\begin{tabular}{|c|c|c|c|c|c|c|c|c|}
\hline \multirow{3}{*}{ No } & \multirow{3}{*}{$\begin{array}{c}\text { Hubungan } \\
\text { Interpersonal } \\
\text { dengan (Atasan) }\end{array}$} & \multicolumn{4}{|c|}{ Stres Kerja } & \multirow{2}{*}{\multicolumn{2}{|c|}{ Jumlah }} & \multirow[b]{2}{*}{ p value } \\
\hline & & \multicolumn{2}{|c|}{$\begin{array}{c}\text { Tidak } \\
\text { Menagalami } \\
\text { Stres Kerja }\end{array}$} & \multicolumn{2}{|c|}{$\begin{array}{l}\text { Menagalami } \\
\text { Stres Kerja }\end{array}$} & & & \\
\hline & & $\mathrm{n}$ & $\%$ & $\mathrm{n}$ & $\%$ & $\mathrm{n}$ & $\%$ & \\
\hline 1 & Buruk & 18 & 15,5 & 26 & 22,4 & 44 & 37,9 & \\
\hline 2 & Baik & 34 & 29,3 & 38 & 32,8 & 72 & 62,1 & 0.507 \\
\hline & Jumlah & 52 & 44,8 & 64 & 55,2 & 116 & 100,0 & \\
\hline
\end{tabular}

Tabel 4 menunjukkan hasil analisis hubungan antara yang tidak mengalami stres kerja dan memiliki hubungan interpersonal dengan atasan yang buruk sebesar 15,5 persen (18 responden) sedangkan yang memiliki hubungan interpersonal dengan atasan yang baik sebesar 29,3 persen (34 responden). Yang mengalami stres kerja kerja dan memiliki hubungan interpersonal dengan atasan yang buruk sebesar 22,4 persen (26 responden) sedangkan yang memiliki hubungan interpersonal dengan atasan yang baik sebesar 32,8 persen (38 responden). Hasil uji statistik diperoleh nilaip-value $=$ 0.507 , yangmemiliki arti tidak ada hubungan yang bermakna antara stres kerja dengan hubungan interpersonal dengan (atasan).

Tabel 5. Hubungan Interpersonal dengan Rekan Kerja dengan Stres Kerja.

\begin{tabular}{|c|c|c|c|c|c|c|c|c|}
\hline \multirow{3}{*}{ No } & \multirow{3}{*}{$\begin{array}{c}\text { Hubungan } \\
\text { Interpersonal } \\
\text { dengan (Rekan } \\
\text { Kerja) }\end{array}$} & \multicolumn{4}{|c|}{$\begin{array}{l}\text { Stres Kerja } \\
\end{array}$} & \multirow{2}{*}{\multicolumn{2}{|c|}{ Jumlah }} & \multirow{3}{*}{ p value } \\
\hline & & \multicolumn{2}{|c|}{$\begin{array}{c}\text { Tidak } \\
\text { Menagalami } \\
\text { Stres Kerja }\end{array}$} & \multicolumn{2}{|c|}{$\begin{array}{c}\text { Menagalami } \\
\text { Stres Kerja }\end{array}$} & & & \\
\hline & & $\mathrm{n}$ & $\%$ & $\mathrm{n}$ & $\%$ & $\mathrm{n}$ & $\%$ & \\
\hline 1 & Buruk & 16 & 13,8 & 12 & 10,3 & 28 & 24,1 & \\
\hline 2 & Baik & 36 & 31,0 & 52 & 44,8 & 88 & 75,9 & 0.132 \\
\hline & Jumlah & 52 & 44,8 & 64 & 55,2 & 116 & 100,0 & \\
\hline
\end{tabular}


Tabel 5 menunjukkan hasil analisis hubungan antara yang tidak mengalami stres kerja dan memiliki hubungan interpersonal dengan rekan kerja yang buruk sebesar 13,8 persen (16 responden) sedangkan yang memiliki hubungan interpersonal dengan rekan kerja yang baik sebesar 31 persen (36 responden). Yang mengalami stres kerja kerja dan memiliki hubungan interpersonal dengan rekan kerja yang buruk sebesar 10,3 persen (12 responden) sedangkan yang memiliki hubungan interpersonal dengan rekan kerja yang baik sebesar 44,8 persen (52 responden). Hasil uji statistik diperoleh nilai $p$-value $=0.132$, yang memiliki arti tidak ada hubungan yang bermakna antara stres kerja dengan hubungan interpersonal dengan (rekan kerja).

Tabel 6. Hubungan Promosi dengan Stres Kerja.

\begin{tabular}{|c|c|c|c|c|c|c|c|c|}
\hline \multirow{3}{*}{ No } & \multirow{3}{*}{ Promosi } & \multicolumn{4}{|c|}{$\begin{array}{c}\text { Stres Kerja } \\
\end{array}$} & \multirow{2}{*}{\multicolumn{2}{|c|}{ Jumlah }} & \multirow[b]{2}{*}{$p$ value } \\
\hline & & \multicolumn{2}{|c|}{$\begin{array}{c}\text { Tidak } \\
\text { Menagalami } \\
\text { Stres Kerja }\end{array}$} & \multicolumn{2}{|c|}{$\begin{array}{l}\text { Menagalami } \\
\text { Stres Kerja }\end{array}$} & & & \\
\hline & & $\mathrm{n}$ & $\%$ & $\mathrm{n}$ & $\%$ & $\mathrm{n}$ & $\%$ & \\
\hline 1 & Tidak Semangat & 59 & 50,9 & 17 & 14,7 & 76 & 65,5 & \\
\hline 2 & Semangat & 23 & 19,8 & 17 & 14,7 & 40 & 34,5 & 0.024 \\
\hline & Jumlah & 82 & 70,7 & 34 & 29,3 & 116 & 100,0 & \\
\hline
\end{tabular}

Hasil tabel 6 terlihat analisis hubungan antara yang tidak mengalami stres kerja dan yang tidak semangat menginginkan promosi (kenaikan jenjang jabatan) sebesar 50,9 persen (59 responden) sedangkan yang semangat menginginkan promosi (kenaikan jenjang jabatan) sebesar 19,8 persen (23 responden). Yang mengalami stres kerja kerja dan yang tidak semangat menginginkan promosi (kenaikan jenjang jabatan) sebesar 14,7 persen (17 responden) sedangkan yang semangat menginginkan promosi (kenaikan jenjang jabatan) sebesar 14,7 persen (17 responden). Hasil uji statistik diperoleh nilai $p$-value $=0.024$, yang memiliki arti ada hubungan yang bermakna antara stres kerja dengan promosi (kenaikan jenjang jabatan). Hal disebabkan karena pengaruh penilaian kinerja dengan promosi, kepuasan kegiatan promosi dan peluang untuk menggunakan keterampilan baru yang dimiliki.

Tabel 7. Hubungan Gaji dengan Stres Kerja.

\begin{tabular}{|c|c|c|c|c|c|c|c|c|}
\hline \multirow{3}{*}{ No } & \multirow{3}{*}{ Gaji } & \multicolumn{4}{|c|}{ Stres Kerja } & \multirow{2}{*}{\multicolumn{2}{|c|}{ Jumlah }} & \multirow[b]{2}{*}{$p$ value } \\
\hline & & \multicolumn{2}{|c|}{$\begin{array}{c}\text { Tidak } \\
\text { Menagalami } \\
\text { Stres Kerja }\end{array}$} & \multicolumn{2}{|c|}{$\begin{array}{l}\text { Menagalami } \\
\text { Stres Kerja }\end{array}$} & & & \\
\hline & & $\mathrm{n}$ & $\%$ & $\mathrm{n}$ & $\%$ & $\mathrm{n}$ & $\%$ & \\
\hline 1 & Tidak Puas & 0 & 0,0 & 2 & 1,7 & 2 & 1,7 & \\
\hline 2 & Puas & 52 & 44,8 & 62 & 53,4 & 114 & 98,3 & 0.198 \\
\hline & Jumlah & 52 & 44,8 & 64 & 55,2 & 116 & 100,0 & \\
\hline
\end{tabular}

Hasil tabel 7. pada analisis hubungan antara yang tidak mengalami stres kerja dan merasakan gaji yang tidak puas sebesar 0,0 persen (0 responden) sedangkan yang puas merasakan gaji sebesar 44,8 persen (52 respponden). Yang mengalami stres kerja dan merasakan gaji yang tidak puas sebesar 1,7 persen ( 2 responden) sedangkan yang puas 
merasakan gaji sebesar 53,4 persen (62 $p$-value $=0.198$, yang memiliki arti tidak ada responden). Hasil uji statistik diperoleh nilai hubungan antara stres kerja dengan gaji.

Tabel 8. Hubungan Peran Dalam Organisasi dengan Stres Kerja.

\begin{tabular}{|c|c|c|c|c|c|}
\hline \multirow[b]{2}{*}{ No } & \multirow[b]{2}{*}{$\begin{array}{c}\text { Peran Dalam } \\
\text { Organisasi }\end{array}$} & \multicolumn{2}{|c|}{$\begin{array}{l}\text { Stres Kerja } \\
\end{array}$} & \multirow[b]{2}{*}{ Jumlah } & \multirow{3}{*}{ p value } \\
\hline & & $\begin{array}{c}\text { Tidak } \\
\text { Menagalami }\end{array}$ & $\begin{array}{l}\text { Menagalami } \\
\text { Stres Kerja } \\
\mathbf{2 0 1 6}\end{array}$ & & \\
\hline 1 & Tidak Mendukung & & & & \\
\hline 2 & Mendukung & 38,8 & 52,6 & 91,4 & 0.094 \\
\hline & Jumlah & 44,8 & 55,2 & 100,0 & \\
\hline
\end{tabular}

Tabel 8. Menunjukkan hasil analisis hubungan antara yang tidak mengalami stres kerja dan tidak mendukung peran dalam organisasi sebesar 6,0 persen (7 responden) sedangkan yang mendukung peran dalam organisasi sebesar 38,8persen (45 responden). Yang mengalami stres kerja dan tidak mendukung peran dalam organisasi sebesar 2,6 persen (3 responden) sedangkan yang mendukung peran dalam organisasi sebesar 52,6 persen (61 responden). Hasil uji statistik diperoleh nilai $p$-value $=0.094$, yang memiliki arti tidak ada hubungan antara stres kerja dengan peran dalam organisasi.
Tabel 9 menunjukkan hasil analisis hubungan antara yang tidak mengalami stres kerja dan cukup untuk masalah ekonominya sebesar 22,4 persen (26 responden) sedangkan yang tidak cukup untuk masalah ekonominya sebesar 22,4 persen (26 responden). Yang mengalami stres kerja dan cukup untuk masalah ekonominya sebesar 24,1 persen (28 responden) sedangkan yang tidak cukup untuk masalah ekonominya sebesar 31,0 (36 responden). Hasil uji statistik diperoleh nilai $\mathrm{p}$-value $=0.502$, yang memiliki arti tidak ada hubungan antara stres kerja dengan masalah ekonomi.

Tabel 9. Hubungan Masalah Ekonomi dengan Stres Kerja.

\begin{tabular}{|c|c|c|c|c|c|c|c|c|}
\hline \multirow{3}{*}{ No } & \multirow{3}{*}{ Masalah Ekonomi } & \multicolumn{4}{|c|}{$\begin{array}{c}\text { Stres Kerja } \\
\end{array}$} & \multirow{2}{*}{\multicolumn{2}{|c|}{ Jumlah }} & \multirow[b]{2}{*}{$p$ value } \\
\hline & & \multicolumn{2}{|c|}{$\begin{array}{c}\text { Tidak } \\
\text { Menagalami } \\
\text { Stres Kerja }\end{array}$} & \multicolumn{2}{|c|}{$\begin{array}{l}\text { Menagalami } \\
\text { Stres Kerja }\end{array}$} & & & \\
\hline & & $\mathrm{n}$ & $\%$ & $\mathrm{n}$ & $\%$ & $\mathrm{n}$ & $\%$ & \\
\hline 1 & Cukup & 26 & 22,4 & 28 & 24,1 & 54 & 46,6 & \\
\hline 2 & Tidak Cukup & 26 & 22,4 & 36 & 31,0 & 62 & 53,4 & 0.502 \\
\hline & Jumlah & 52 & 44,8 & 64 & 55,2 & 116 & 100,0 & \\
\hline
\end{tabular}

Sumber: Hasil Penelitian, 2016

\section{SIMPULAN DAN SARAN}

Berdasarkan hasil penelitian yang telah dilakukan pada petugas Pemadam Kebakaran sejumlah 116 responden yang bekerja di Pemadam Kebakaran Kompi C Kota Padang
Tahun 2016, dapat disimpulkan sebagai bahwa responden yang mengalami stres sebesar 29,3 persen (34 responden), diikuti dengan responden yang tidak mengalami stres kerja sebesar 70,7 persen (82 responden), adanya hubungan antara stres 
kerja dengan beban kerja memiliki $p$ value $=0,020$. Adanya hubungan antara stres kerja dengan rutinitas kerja memiliki $p$ value $=0,033$. Adanya hubungan antara stress kerja dengan promosi (kenaikan jenjang jabatan) memiliki $p$-value $=0,024$.

Saran yang dapat diberikan antara lain pemberian atau pembekalan seminar yang berkaitan dengan stres kerja kepada petugas Pemadam Kebakaran yang diberikan oleh Suku Dinas Pemadam Kebakaran setiap 6 bulan sekali untuk memotivasi para petugas agar tidak bosan dengan rutinitas pekerjaan yang itu-itu saja atau monoton, melakukan manajemen stres dengan berfikir positif terhadap kemampuan diri dan mengembangkan keterampilan diri dalam bekerja serta membangun relasi dengan rekan kerja di perusahaan saat ini atau tempat lain.
Langkah yang bisa dilakukan adalah mengevaluasi tugas dan kewajiban para petugas sesuai dengan latar belakang pendidikan dan jabatannya dalam lingkungan kerjanya, pembinaan kegiatan olahraga dan kesegaran jasmani yang dilakukan seminggu sekali. Seperti bermain sepak bola, bulutangkis, volley dan lain sebagainya, untuk menjaga hubungan interpersonal dengan atasan ataupun sesama rekan kerja tetap baik, maka diperlukan kegiatan team building secara berkesinambungan antar atasan ataupun rekan kerja (minimal 3 bulan sekali), mengadakan kegiatan konseling sebagai sarana bagi petugas lapangan Pemadam Kebakaran dalam menyampaikan permasalahan yang dihadapi. 


\section{DAFTAR PUSTAKA}

Arden, J. B. (2006). Bekerja Tanpa Stres, Terjemahan: Tanto Hendy. Padang: PT. Bhuana Ilmu Populer.

Ciccarelli, Saundra K, \& Meyer. (2005). Psycholog. New Jersey: Pearson Education Learning.

Cooper, Caryl., Davidson, Marilyn. (1987). Source of Stres at Work and Their Relation to Stressors in Non- Working Environmen, Dalam: World Health Organization. Psychosocial Factors at Work and Their relation to Health, Geneva: World Health Organization.

Cox, Tom., Amanda, Griffiths., dan Eusobio Rial-Gonzales. (2000). Research on Work-related Stress. European agency for Safety and Health at Work. Luxemburg.

Desy, Vita Helia. (2002). Tingkat Stres Kerja dan Faktor-faktor yang Berhubungan dengan Stres Kerja Pada Karyawan Bagian Marketing Services PT. Unilever Indonesia Tbk Padang Tahun 2012. Skripsi (Tidak diterbitkan). Depok: Fakultas Kesehatan Masyarakat Universitas Indonesia.

Early, Evy. (2003) Faktor-Faktor Organisasi yang Menimbulkan Stres Kerja Pada Perawat Pelaksana di Ruang Rawat Inap Rumah Sakit Husada. Skripsi (Tidak diterbitkan). Depok: Fakultas Kesehatan Masyarakat Universitas Indonesia.

Ernst, M.E., Franco, M., Messmer, P. R., and Gonzalez, J. L. (2004). Nurses' Job Satisfaction, Stress, and Recognition in a Pediatric Setting. Pediatric Nursing. Vol. 30(3), pp. 219-227.

Handoko, Hani T. (1985). Manajemen Personalia dan Sumber Daya Manusia. Yogyakarta: Liberty.

Kreitner, R and Kinicki, A. (1992). Organizational Behaviour; Second Edition. Boston: Irwain.

Levi, L. (1984). Stres In Industry: Causes, Effect and Prevention. Geneva: International Labour Organization.

Miller, David. (2000). Dying to Care? Work Stress and Burnout in HIV/AIDS. London: Routledge.

Munandar, A. S. (2006). Psikologi Industri dan Organisasi. Depok: UI Press.

National Safety Council. (1994). Manajemen Stres. Jakarta: EGC.

Prayitno, A. (1996). Pengendalian Stres Pekerja dengan Teknik Relaksasi Asertif dalam Seminar Standarisasi dan Sertifikasi Keselamatan dan Kesehatan Kerja.

Robbins, Stephen P. (1996). Perilaku Organisasi. Edisi ke 7 (Jilid II). Jakarta: Prehallindo.

Satriani, I Gusti ayu. (1998). Peranan Hubungan Antara Pribadi Faktor Organisasi dan Faktor Pekerjaan Dalam Timbulnya Job Stres di Kalangan Tenaga Keperawatan Wanita Rumah Sakit Fatmawati Padang. Tesis (Tidak diterbitkan). Depok: Program Magister Fakultas Kesehatan Masyarakat Universitas Indonesia. 